Рецензия на книгу:

Sokthan Yeng

Buddhist Feminism: Transforming Anger against Patriarchy. -

London: Palgrave Macmillan, 2020. — xii + 152 pp. -

ISBN 978-3-030-51162-3

С.Л. БУРМИСТРОВ

Институт восточных рукописей РАН

Санкт-Петербург, Россия

DOI: $10.17816 /$ WMO83940

Рецензия поступила в редакцию 12.05.2021.

Ключевые слова: буддийская философия, современный буддизм, феминизм, дискриминация, гендерные исследования.

Для цитирования: Бурмистров С.Л. Рец. на: Sokthan Yeng. Buddhist Feminism: Transforming Anger against Patriarchy. - London: Palgrave Macmillan, 2020. - xii + 152 pp. // Письменные памятники Востока. 2021. Т. 18. № 4 (вып. 47). С. 130-135. DOI: 10.17816/WMO83940.

Об авторе: БУРМИСТРОВ Сергей Леонидович, доктор философских наук, ведущий научный сотрудник Отдела Центральной и Южной Азии ИВР РАН (Санкт-Петербург, Россия) (SLBurmistrov@yandex.ru).

(С Бурмистров С.Л., 2021

Общеизвестно значение феминистской идеологии для современной культуры и общества. Довольно много есть и исследований, посвященных роли религиозно-философских систем Востока в культуре современного Запада. Однако изучением возможного значения культур Востока для феминистской идеологии не занимался, насколько нам известно, пока никто. Идеология феминизма для подкрепления своих позиций привлекает в том числе и буддийское учение, переосмысляя его так, что оно из самостоятельного явления мировой культуры становится средством для достижения политических целей феминистского движения. По рецензируемой книге хорошо видно, как выработанные в феминизме понятия гнева (anger) и угнетения, через призму которых рассматривается буддизм, делают его лишь одним из элементов феминистской идеологии.

Автор книги - Соктхан Ен, ассоциированный профессор университета Адельфи (Нью-Йорк). Она окончила университет Толедо (Огайо) в 2001 г. и защитила докторскую диссертацию (PhD) в университете Де-Пол (DePaul) в Нью-Йорке в 2007 г. Ее перу принадлежит ряд трудов по идеологии феминизма, биополитике, проблемам расизма, но вопросов буддийской философии она в своей работе касается впервые. Несмотря на серьезные недостатки в изложении и интерпретации буддийского учения, о которых будет сказано ниже, рассматриваемая монография интересна хотя бы уже тем, что в ней буддийская философия и догматика анализируются с точки зрения 
современной феминистской идеологии с целью выявить в них то, что может быть практически полезным для развития феминистского движения.

Прежде всего следует отметить, говорит автор, что ни буддизм, ни феминизм не являются сколько-нибудь монолитными мировоззренческими системами - в них есть течения с существенно различными взглядами. Впрочем, в феминистской идеологии имеется все же одна универсальная, с точки зрения автора, черта: эта идеология до сих пор, несмотря на все усилия борцов с институциализированным расизмом, разрабатывается в основном белыми женщинами, представительницами среднего и высшего классов общества (white bourgeois women, как прямо пишет Соктхан Ен на c. 1), что ограничивает и возможности самого феминизма, и спектр проблем, которые могут быть подняты его идеологами. Это, помимо всего прочего, делает общество «слепым» по отношению к проблемам, с коими сталкиваются женщины из среды иммигрантов-неевропейцев. Одна из особенностей американского буддийского общества состоит в том, что его идеология направлена на более активное включение женщин и отводит им бо́льшую общественную роль, чем это имеет место, например, в буддийских обществах Азии. Другая - это его ориентация на достижение политических целей, что роднит его с феминистским движением (с. 2). Последнее в рамках буддийской сангхи в США нацелено на достижение политических целей (конкретно - на преодоление патриархата, традиционного господства мужчин в обществе), используя в качестве инструмента буддийское учение (с. 2-3). Женщины - и особенно небелые женщины - до сих пор, полагает автор, недопредставлены в американской политике, а буддийские лидеры даже в самих США не уделяют этой проблеме достаточного внимания (с. 3). Вопрос о реальных масштабах угнетения Соктхан Ен оставляет за рамками своей работы.

Характерная черта буддийского мировоззрения, делающая его более прочной идеологической базой для феминизма по сравнению с философскими системами Запада, по мнению автора, — в принципиально ином понимании природы субъекта в буддизме. В западной философии, полагает Соктхан Ен, субъект автономен по отношению к обществу, а в буддизме «я» всегда рассматривается как часть общества, зависящая от социального и культурного контекста (с. 3). Разумеется, в действительности все значительно сложнее, и автор радикально упрощает картину философской мысли Запада (фактически Соктхан Ен говорит здесь только о новоевропейском рационализме Декарта, Спинозы, Канта и др., исключая из рассмотрения даже, например, американский прагматизм, не говоря уже о европейской философии $\mathrm{XX}$ в., где автономия субъекта в большинстве течений ставится под вопрос), но важно, что для нее философия Запада в первую очередь рациональна. Нельзя, конечно, прямо утверждать, что здесь автор монографии прибегает к известному демагогическому приему ignoratio elenchi, при котором участник дискуссии искажает взгляды оппонента, подменяя их похожими, но абсурдными и потому заведомо легко опровергаемыми, но, во всяком случае, приписывание всей западной философии ориентации на автономию субъекта - обобщение слишком широкое, чтобы быть верным.

Одно из важных понятий идеологии феминизма - anger, что буквально значит «гнев», но в феминистском контексте приобретает значение подавленного и не имеющего выхода чувства негодования и обиды, отравляющего психику, подобно тому как гноящаяся рана отравляет кровь. В современном западном обществе, полагает автор, проявление гнева воспринимается как признак неспособности человека ответить на вызов рационально. Гнев считается чем-то противоположным разуму. В буддизме, однако, проявление гнева и негодования - даже со стороны женщины - не считается признаком слабости разума, поэтому в буддийском феминизме гнев может восприни- 
маться как определенный вклад в философию; в этом состоит еще один аспект буддизма, по мнению автора, политически важный для феминистского движения (с. 6).

Однако само буддийское мировоззрение, чтобы быть полезным для феминистской политики, должно быть определенным образом изменено. Буддийские общины не настолько открыты для женщин - представительниц расовых, этнических и других меньшинств и вообще для носителей «уязвимых „я“» (vulnerable selves), как это может показаться человеку, знакомому с буддизмом лишь по книгам. Это только в теории буддизм открыт всем, на практике же лидеры - а следом за ними и рядовые члены буддийских общин продолжают маргинализировать меньшинства и об инклюзивизме и недискриминации в основном говорят, но ничего реально не делают (с. 9). Соктхан Ен усматривает корни этого в специфическом восприятии гнева как неспособности мыслить и действовать рационально и в укорененном в массовом сознании расизме, через призму которого «цветные» (и в особенности цветные женщины) гораздо меньше способны контролировать себя и действовать рационально и поэтому нуждаются в господстве со стороны белых, подобно тому как и над гневом должен господствовать разум (с. 10). На этом предрассудке строили свои концепции и западные философы прошлого, оправдывая мужское превосходство рациональностью мужчин и эмоциональностью женщин (с. 15).

При этом - отчасти противореча сама себе - Соктхан Ен, анализируя взгляды Аристотеля на сферу эмоций, отмечает, что, согласно ему, гнев далеко не всегда представляет собой проявление слабости разума и эмоциональной нестабильности. Аристотель указывал, что гнев часто бывает оправдан, а тот, кто не испытывает гнева даже при виде несправедливости, скорее всего, просто лишен мужества или настолько туп, что не может отличить справедливое от несправедливого. Тот, кто не способен сдержать свой гнев, - раб своих эмоций, а тот, кто никогда не испытывает его, - раб своей трусости (с. 18).

Аналогично рассматривается эта эмоция и в буддийской философии. Гнев - это не враг, которого надо победить или изгнать, а состояние, вызванное определенными причинами и приводящее к страданию, так что работа над ним предполагает анализ и устранение страдания, вызвавшего его, а не простое его подавление (с. 28). Справедливости ради надо отметить, что такая же работа с эмоциями (и не только гневом) характерна и для обычной западной психологии - как минимум со времен Фрейда, если не раньше, - так что буддизм здесь отнюдь не уникален.

Один из аспектов буддийского учения, который Соктхан Ен находит важным для феминистской идеологии, - это anātman, учение о несуществовании постоянного «я»: представление о нем есть всего лишь ментальный конструкт, порожденный изначально укорененными в сансарическом сознании аффектами. Никакая идентичность, никакая эго-концепция с этой точки зрения не может считаться истинной: все они изменчивы, поэтому не имеет смысла привязываться ни к какой из них (с. 36). Это, конечно, тоже очень «феминистский» вывод, ибо, согласно идеологии этого движения, никакие идентичности, включая гендерные, не могут считаться имманентными - все они порождены определенной социальной и культурной средой и могут меняться в зависимости от нее. Все это, с точки зрения автора, сближает буддийское учение с идеями некоторых идеологов феминизма - например, Джудит Батлер (с. 36). Опирается она при этом на сравнение их идей с воззрениями современного буддийского мыслителя Тхить Нят Ханя. Он указывает, в частности, что учение о «не-я» в буддизме означает просто зависимость «я» от всего остального в мире, и, подобно Джудит Батлер и Юлии Кристевой, полагает метафизическое противопоставление «я» и мира корнем множества противоречий, в рамках такого взгляда на субъект-объектные отношения непреодолимых в 
принципе (с. 37). Иначе рассматривает Тхить Нят Хань и понятие пустоты (śūnyatā), роль которого в философии буддизма махаяны общеизвестна. Европейские мыслители (Соктхан Ен не указывает, кто именно) отождествляют пустоту с ничто, тогда как Тхить Нят Хань считает ее тождественной полноте реальности. Такая позитивная концепция «не-я» открывает путь к более полному пониманию не только реальности вообще, но и гендерных реалий в частности. Иными словами, женский пол - это не реалия «в себе», а нечто, что существует лишь в отношениях с другими реалиями - гендерными, социальными, культурными, экономическими (с. 38). Здесь Соктхан Ен обращается к учению о двух истинах - относительной и абсолютной; это учение характерно на самом деле лишь для махаяны, но автор монографии приписывает его буддизму вообще. Относительная истина, говорит она, зависит от социальных и культурных условностей, так что ее определяет общество. Абсолютная же истина пребывает выше всех различий и условностей, но с ее высот вся реальность предстает сетью взаимных зависимостей между разными реалиями. Это, по мнению автора, означает, что абсолютная реальность зависима от относительной: для передачи абсолютного знания нужны слова или иные знаки, которые сами принадлежат уровню относительной истины (с. 38). Все это демонстрирует истинный - очень низкий - уровень познаний Соктхан Ен в буддийской философии. На самом деле, конечно, в философии махаяны абсолютная истина от относительной никоим образом не зависит - достаточно обратиться к фундаментальным махаянским трактатам («Мула-мадхьямака-карика» Нагарджуны с комментарием Чандракирти, «Мадхьямака-аватара» Чандракирти, «Абхидхарма-самуччая» и «Махаяна-сампариграха-шастра» Асанги), чтобы увидеть это. Более того, никакая передача абсолютной истины невозможна - эту истину можно только узреть самому, освободившись от аффектов, а все слова и концепции махаяны не более чем инструменты, призванные так трансформировать сознание адепта, чтобы прозрение абсолютной истины стало возможным.

Значение буддизма для феминизма связано, по мысли Соктхан Ен, также и с присущей, как считается, женщинам этикой заботы, которой отчасти обусловлено и то, что именно женщины особенно активно распространяют буддийское учение и на Западе, и на Востоке (с. 55-56). Для подкрепления этой идеи автор обращается к исследованию Деборы Орр, где было показано, что уже среди детей девочки более чувствительны к тонкостям межличностных отношений, чем мальчики, и стремятся к установлению и поддержанию гармонии в обществе. Любую моральную проблему мальчики решают как математическую задачу, стремясь получить ясный и однозначный ответ, тогда как девочки принимают во внимание чувства тех, кого проблема касается, и стремятся, скорее, к такому решению, которое обеспечило бы общее благополучие (с. 57). Такую же установку она находит и в буддизме.

Люс Иригарей, один из ведущих идеологов феминизма, находит, что акцент на медитативной практике позволяет создать особенно позитивный контекст для женского тела (provides positive context for the female body), что делает женщин более видимыми в обществах буддийской культуры, чем западной, и повышает ценность женского начала, оцениваемого в западной культуре почти всегда значительно ниже мужского (c. 38). Это, строго говоря, тоже попытка выдать желаемое за действительное: общеизвестно подчиненное положение женщин в традиционных обществах, в которых доминирующей религией является буддизм; в буддийском дисциплинарном кодексе монахиням предписывается соблюдать значительно больше правил, чем монахам; хорошо известно также высказывание из буддийского Канона, что монахиня, даже принявшая монашеские обеты сто лет назад, должна оказывать почтение монахумужчине, даже если он принял монашество только накануне. Все это, конечно, не 
смущает автора, так как задача Соктхан Ен - не проанализировать статус женщин в буддийских обществах, а доказать применимость буддийского учения для политических целей феминистского движения.

Впрочем, автор отмечает и ограничения, делающие прямое использование буддизма в феминистском движении невозможным. В первую очередь это приписываемая женщинам иррациональность, проявляющаяся в том, что они даже в религии ищут порой некие мистические силы, не существующие на самом деле. В буддийских текстах женщины иногда описываются как препятствия для мужчин на пути к нирване (с. 60), что делает необходимой известную трансформацию буддийского учения, чтобы оно могло стать частью феминистской идеологии.

Иногда буддийская идеология воспринимается - в том числе и некоторыми феминистками - как идеология, исключающая всякую дискриминацию, включая расовую, гендерную и др. Но это, отмечает Соктхан Ен, в действительности не так: различия порой не только не сглаживаются, но даже подчеркиваются - не в текстах уже, а в реальной социальной практике. Так, распространение буддизма в США привело к возникновению еще одного различия - между американцами, сознательно принявшими буддизм, и потомками иммигрантов, для которых буддизм был традиционной религией. Особенно остро проявляется такая дискриминация по отношению к афроамериканцам, вступившим в буддийские общины в надежде, что там никакой дискриминации уже не будет (с. 78, 80-82). Одна из политических целей феминизма - преодоление также и этой дискриминации, стирание различия между «обращенными» и «наследственными» буддистами (convert and heritage Buddhists). Такова одна из целей проповеди Тхить Нят Ханя, в которой буддизм обретает очевидное политическое измерение (с. 95). Дискриминацию «обращенных» буддистов Соктхан Ен находит странной, отмечая, что само буддийское учение более всего распространилось за пределами того региона, где возникло (с. 99-100); то же самое, к слову, можно сказать и о христианстве. Политика идентичности - национальной, расовой, гендерной и т.д. — не может поэтому опираться на какие бы то ни было имманентные данности и предполагает, что любая идентичность текуча и зависит от социокультурного контекста. Только на уровне относительной истины существует какое-то постоянное «я», на самом же деле оно зависит от множества внешних по отношению к личности факторов и потому постоянно изменяется (этот вывод тоже важен для феминистской идеологии). Все это открывает возможности конструирования пограничных идентичностей (border identities), отсутствующих в западной философии, и базисом для этого может быть буддизм (с. 100).

Но, по мнению автора, не следует воспринимать буддизм как идеологию, безусловно способствующую преодолению дискриминации и угнетения. Дуализм угнетателя и угнетенного, сохраняющийся в концепциях постколониального феминизма, затрудняет преодоление угнетения, маскируя тот факт, что от угнетения страдают обе стороны, и использование буддийских идей и понятий способно выявить это для массового сознания. Но нельзя не признать, что и буддийское общество может быть источником дискриминации и угнетения (с. 102). Работа с гневом и ресентиментом должна проводиться и в буддийских общинах с опорой на буддийское учение, где его применение в этом направлении будет особенно эффективным. Хотя традиционная буддийская литература (Соктхан Ен не уточняет при этом, что именно имеется в виду) изображает гнев исключительно негативно, современные буддийские мыслители рассматривают его уже несколько иначе, признавая его позитивную роль в политических трансформациях (с. 104). Из этих замечаний тоже хорошо видно, что автор монографии ставит своей целью не исследование буддизма как такового, а анализ возможного применения буддизма как инструмента политических изменений. 
Буддизм сближает друг с другом иммигрантов из разных стран Азии (Таиланд, Лаос, Камбоджа и др.) - что, впрочем, создает новую проблему: социальная роль буддизма в этих общинах преувеличивается и в глазах их собственных членов, и тем более - в глазах внешних наблюдателей, значение же буддизма как духовного учения, наоборот, преуменьшается. В то же время члены буддийских общин, состоящих в основном из американцев, принявших эту религию сознательно, часто считают, что именно у них наиболее полно сохраняется и культивируется дух буддизма или даже буддизм в его «истинной» форме - как духовное учение, а не только базис для социального взаимодействия. Все это - проявления того же самого «колониального мышления», которое приписывает представителям западной культуры больший (по сравнению с носителями других культур) вкус к философии, что свидетельствует, в соответствии с этим типом мышления, и о более высоком интеллекте (с. 120). Такой тип мышления, естественно, должен быть преодолен, чему может способствовать, среди прочего, также и изучение буддизма.

Общая идея рецензируемой монографии вполне понятна: буддизм, как сказано выше, важен для автора не сам по себе, а как средство политических трансформаций. Направление их тоже очевидно: преодоление дискриминации и угнетения, прежде всего - угнетения гендерного. Автор не анализирует ни реальные социальные практики в странах буддийского ареала или в буддийских общинах США, ни рецепцию буддизма в западной культуре, ни особенности взаимодействия буддийских общин с «внешним» по отношению к ним обществом, ни реальное положение женщин в буддийских общинах. Рассматриваемая книга имеет в первую очередь феминистский характер, она направлена на продвижение феминистских идей в обществах буддийской культуры и на включение буддийских общин в странах Запада в политическую борьбу на стороне феминистского движения и поэтому не может считаться в полной мере научной. Она интересна в другом качестве - как идеологическая (в марксистском смысле) работа, в которой автор ищет пути использования буддизма как инструмента для достижения целей феминистского движения. Искажения реальной картины буддийского учения в таких случаях, конечно, естественны, так как задача автора - использовать буддизм, а не понять его.

Review of the book:

\section{Sokthan Yeng}

Buddhist Feminism: Transforming Anger against Patriarchy.

London: Palgrave Macmillan, 2020, xii + 152 pp. ISBN 978-3-030-51162-3

Sergey L. BURMISTROV

Institute of Oriental Manuscripts RAS

St. Petersburg, Russian Federation

Received 12.05.2021.

Key words: Buddhist philosophy, contemporary Buddhism, feminism, discrimination, gender studies.

For citation: Burmistrov, Sergey L. "Rev.: Sokthan Yeng. Buddhist Feminism: Transforming Anger against Patriarchy. London: Palgrave Macmillan, 2020. xii + 152 pp. ISBN 978-3-030-51162-3”. Pis'mennye pamiatniki Vostoka, 2021, vol. 18, no. 4 (iss. 47), pp. 130-135 (in Russian). DOI: 10.17816/WMO83940.

About the author: Sergey L. BURMISTROV, Dr. Sci. (Philosophy), Leading Researcher, Section of South Asian Studies of the Department of Central Asian and South Asian Studies, Institute of Oriental Manuscripts, Russian Academy of Sciences (St. Petersburg, Russian Federation) (SLBurmistrov@yandex.ru). 